\title{
Chemical Composition and Antimicrobial Activity of the Essential Oil of the Leaves of Cupressus macrocarpa Hartweg. ex Gordon
}

\author{
Amal M. Saad ${ }^{1}$, Magdy M.D. Mohammed ${ }^{2}$, Mosad A. Ghareeb ${ }^{1 *}$, Wafaa S. Ahmed ${ }^{1,3}$, Mohamed A. Farid ${ }^{4}$ \\ ${ }^{1}$ Department of Medicinal Chemistry, Theodor Bilharz Research Institute, Kornish El-Nile, 12661 Warrak El-Hadar, Giza, Egypt. \\ ${ }^{2}$ Pharmacognosy Department, Pharmaceutical and Drug Industries Research Division, National Research Centre, Dokki-12622, Cairo, Egypt. \\ ${ }^{3}$ Department of Chemistry, College of Science and Arts, Sajir, Shaqra University, Kingdom of Saudi Arabia. \\ ${ }^{4}$ Chemistry of Natural and Microbial Products Department, Pharmaceutical and Drug Industries Research Division, National Research Centre, Dokki- \\ 12622, Cairo, Egypt.
}

\begin{tabular}{l} 
ARTICLE INFO \\
\hline Article history: \\
Received on: $13 / 05 / 2017$ \\
Accepted on: 04/07/2017 \\
Available online: $30 / 09 / 2017$ \\
\hline Key words: \\
Monterey Cypress, \\
Cupressaceae, Volatile \\
constituents, GC/MS, \\
GC/FID, Antibacterial \\
activity, Antifungal activity, \\
MIC.
\end{tabular}

\section{INTRODUCTION}

Cupressus macrocarpa (Hartweg. ex Gordon) as a medicinal plant belongs to the family Cupressaceae and commonly known as Monterey Cypress (Cool, 2005; Thukral et al., 2014). It is widely distributed throughout the tropical and temperate regions around the world i.e., Mexico, North America Asia, and North Africa (El-Ghorab et al., 2007). C. macrocarpa was used traditionally for decades for the treatment of various ailments, e.g., styptic problem, eliminates fluid retention, whooping cough and rheumatism (Thukral et al., 2014). C.

\footnotetext{
* Corresponding Author

Mosad Ahmed Ghareeb, Department of Medicinal Chemistry, Theodor Bilharz Research Institute, Kornish El-Nile St., Warrak El-Hader, Imbaba, Giza, Egypt. E-mail: m.ghareeb@tbri.gov.eg,

Tel: +2 01012346834, Fax: +20235408125.
}

macrocarpa received little concern regarding its phytochemical constituents; Cool (2005) reported the isolation of ten sesquiterpenes from its foliage. Furthermore, Al-Sayed and AbdelDaim (2014) investigated the protective role of the isolated cupressuflavone from $C$. macrocarpa against $\mathrm{CCl}_{4}$ induced hepatoand nephrotoxicity in mice.

Several Cupressus species have been investigated for their essential oil content and evaluated for biological activity. ElGhorab et al. (2007) identified 43 components from the fresh and dried leaves of the Egyptian $C$. macrocarpa that showed remarkable antimicrobial and antioxidant activities. In addition, thirteen components from the Iranian $C$. sempervirens $\mathrm{L}$. were identified (Emami et al., 2004) and investigated for activity as fungistatic and bacteriostatic activity. Allo-ocimene along with other fourteen components were identified from the Egyptian $C$. sempervirens (Ibrahim et al., 2009), which exhibited promising antimicrobial and antiviral activities. 
Furthermore, Boukhris et al. (2012) identified 24 components from the Tunisian $C$. sempervirens essential oil and evaluated their antioxidant and antimicrobial activities. The aims of the current study were to analyze the essential oil composition of the Egyptian C. macrocarpa fresh leaves qualitatively by GCMS and quantitatively via GC-FID, as well as the evaluation of the antimicrobial activity against eight pathogenic microbial strains.

\section{MATERIAL AND METHODS}

\section{Plant material}

Fresh leaves of Cupressus macrocarpa Hartweg. ex Gordon (Cupressaceae) were collected from the Zoo Garden, Giza, Egypt in June 2014. The plant was identified by Mrs. Threase Labib, consultant of plant taxonomy at the Ministry of Agriculture; formerly, the head of taxonomist specialists at the garden, a voucher specimen (No.C10/1/4) was kept at the herbarium of the garden.

\section{Essential oil isolation}

The fresh leaves of $C$. macrocarpa (2 $\mathrm{kg})$ were fragmented into small pieces and subjected to hydrodistillation using Clavenger apparatus (Ibrahim et al., 2015) to extract the essential oil which was determined as mean of triplicate. The chemical composition of the oil was determined quantitatively via GC-FID and qualitatively via GC-MS by comparing their retention times and mass spectral fragmentation patterns with previously reported data (Adams, 1989, 2001, 2012).

\section{Gas chromatography-mass spectrometry (GC-MS) analysis}

The GC-MS analysis was performed using a Thermo Scientific, Trace GC Ultra/ISQ Single Quadrupole MS and TGSMS Fused Silica Capillary Column $(30 \mathrm{~m}, 0.25 \mathrm{~mm}, 0.1 \mathrm{~mm}$ Film thickness). For GC-MS detection, an electron ionization system with ionization energy for $70 \mathrm{ev}$ was used as the carrier gas at a constant flow rate of $1 \mathrm{~mL} / \mathrm{min}$. The injector and MS transfer line temperature was set at $280^{\circ} \mathrm{C}$. The oven temperature was programmed at an initial temperature $40^{\circ} \mathrm{C}$ (hold $3 \mathrm{~min}$.) to $280^{\circ} \mathrm{C}$ was a final temperature at an increasing rate of $5^{\circ} \mathrm{C} / \mathrm{min}$ (hold 5 min). The identified components were investigated using a percent relative peak area. A tentative identification of the volatile compounds was performed based on the comparison of their relative retention time and mass spectra with those of the NIST08s, WILLY8, Adams and Library data of the GC/MS system (Adams, 1989, 2001, 2012; Ghareeb et al., 2016).

\section{Gas Chromatography-Flame Ionization Detector (GC-FID) analysis}

The GC-FID analyses were carried out with a Varian 3400 apparatus (Varian GmbH, Darmstadt, Germany) equipped with a FID detector and a DB-5 fused-bonded capillary column (30m x $0.25 \mathrm{~mm}$ i.d., film thickness $0.25 \mu \mathrm{m}$; Ohio Valley, Ohio, USA). The oven temperature was programmed isothermal at $45^{\circ} \mathrm{C}$ for $2 \mathrm{~min}$., then rising from $45^{\circ} \mathrm{C}$ to $300^{\circ} \mathrm{C}\left(4^{\circ} \mathrm{C} / \mathrm{min}\right.$. $)$, and finally held isothermal at $300^{\circ} \mathrm{C}$ for $20 \mathrm{~min}$; injector temperature was $250^{\circ} \mathrm{C}$; detector temp. was $300^{\circ} \mathrm{C}$; Helium gas was used as carrier gas $\left(2.0 \mathrm{~mL} / \mathrm{min}\right.$.); split ratio, 1:20. Peak Simple ${ }^{\circledR} 2000$ chromatography software (SRI Instruments, California, USA) was used for recording and integrating the chromatograms. Average areas under the peaks of three independent chromatographic runs were used for calculating the $\%$ composition of each component.

\section{Antimicrobial activity of the essential oil Test organisms}

The bacteria used in this study were Gram-positive bacterial strains Bacillus subtilis NRRL 543 and Staphylococcus aureus NRRLB-313 and Gram-negative bacterial strains, Escherichia coli NRRL B-210 and Pseudomonas aeruginosa NRRL B-23. Fungi, Aspergillus niger NRRL 599, Fusarium oxysporum NRRL 28184, Candida albicans NRRL Y-477 and Fusarium solani. These micro-organisms were obtained from Northern Utilization Research and Development Division, United State Department of Agriculture, Peoria, Illinois, USA.

\section{Screening test}

The bacterial strains were revived for bioassay by subculturing in fresh nutrient broth medium for 24 hours before test, while fungi were cultured on potato dextrose agar (PDA) $(2.5 \%$ w/v agar) for 7 days at $28^{\circ} \mathrm{C}$ before the experiment was carried out.

\section{Agar diffusion method}

Cup plate agar diffusion method has been employed for the determination of the antimicrobial activity of some essential oils as well as paraffin oil. Several test microbes including G+ve bacteria (B. subtilis and $S$. aureus), G-ve bacteria ( $P$. aeruginosa and $E$. coli) and fungi (C. albicans, $F$. oxysporum, $A$. niger and $F$. solani) were applied. $1 \mathrm{~mL}$ of cell suspension of $24 \mathrm{~h}$-old bacterial cultures $\left(10^{7}-10^{8}\right.$ colonies $\left./ \mathrm{ml}\right)$ in sterile distilled water was added to $250 \mathrm{~mL}$ of sterile solidified nutrient agar medium. For fungal strains, $1 \mathrm{~mL}$ spore suspension of seven days cultures fungal cultures $\left(10^{6}-10^{7}\right.$ colonies $\left./ \mathrm{mL}\right)$ was added to $250 \mathrm{~mL}$ sterile solidified PDA (potato dextrose agar) medium. Holes of $9 \mathrm{~mm}$ in diameter were made using a cork borer. Aliquots of $0.1 \mathrm{~mL}$ of the diluted essential oil with paraffin oil were poured inside the holes. A hole filled with paraffin oil only was also used as control. The plates were left for $2 \mathrm{~h}$ at $4^{\circ} \mathrm{C}$ as a period for diffusion. The diameter of each inhibition zone was measured and compared with that of the standard. Plate cultures were kept in an incubator at $28^{\circ} \mathrm{C}$ for $48 \mathrm{~h}$ for fungi and at $37^{\circ} \mathrm{C}$ for $24 \mathrm{~h}$ for bacteria (Linday, 1962). Streptomycin and Nystatin were used as control antibiotics at a concentration of 50 and $100 \mu \mathrm{g} / \mathrm{mL}$ respectively. Following incubation, the zone of inhibition for each sample was recorded in mm (including the hole).

Microorganisms with inhibition zone diameter $\geq 28 \mathrm{~mm}$ were classified as strongly sensitive, while that of $<28-16 \mathrm{~mm}$ were moderately sensitive, and with $<16-12 \mathrm{~mm}$ assorted as 
weakly sensitive and isolates with zone diameter of $<12 \mathrm{~mm}$ as resistant (Bauer et al., 1996; Elgayyar et al., 2001).

\section{The minimum inhibitory concentration (MIC)}

Stock solutions of the EO were diluted and transferred into the first tube, and serial dilutions were prepared with concentrations ranged from $0.001-0.02 \mu \mathrm{L} / \mathrm{mL}$. Spore suspension $(10 \mu \mathrm{L})$ of each strain was inoculated in nutrient medium and incubated for $24-72$ hours at $37^{\circ} \mathrm{C}$. The control tubes containing the same medium were inoculated only with bacterial strains suspension. The minimal concentrations at which no visible growth was observed were defined as the MICs and expressed in (v/v \%) (Carson et al., 1995).

\section{RESULTS AND DISCUSSION}

\section{Identification of the essential oil constituents}

Analyses of the essential oil of $C$. macrocarpa resulted in the identification of 15 components (Table 1) representing $86.43 \%$ of the total oil composition, which were identified qualitatively (GC-MS, Fig. 1) based on their retention times and mass spectral fragmentation patterns, and quantitatively (GC-FID, Fig. 2) based on the average areas under the peaks of three independent chromatographic runs into; $\alpha$-terpineol $(19.01 \%)$, camphenilone (9.78\%), elemol (8.92\%), 2-tridecanone (8.75\%), $\alpha$-terpinyl acetate $(8.62 \%), 2$-pentyl-2-cyclopenten-1-one $(6.90 \%)$ and $\beta$ bisabolol $(5.83 \%)$, and other components. The EOs composition of the genus Cupressus can be affected by many factors such as genetics (species or variety) or origin (El-Ghorab et al., 2007; Ibrahim et al., 2009), nutritional conditions such as fertilization, pesticide use, latitude (Emami et al., 2004; El-Ghorab et al., 2007; Boukhris et al., 2012), harvest time (Briggs and Sutherland, 1942), and drying (El-Ghorab et al., 2007). Moreover, the distillation time has been shown to influence the essential oil yield and composition (Zheljazkov et al., 2013).

In brief, El-Ghorab et al. (2007) studied the essential oil content of $C$. macrocarpa leaves (fresh and dried) and concluded that the EO yield of the dried leaves was more than the fresh one, with neral as the major constituent $(35 \%)$ together with camphene $(0.21 \%), \alpha$-terpinyl acetate $(1.48 \%)$ and camphenilone $(0.32 \%)$. In our study, $\alpha$-terpineol $(19.01 \%)$ was the major together with camphene $(1.49 \%), \alpha$-terpinyl acetate $(8.62 \%)$, and camphenilone $(9.78 \%)$.

Briggs and Sutherland (1942) reported that the EO content of $C$. macrocarpa leaves was $20 \%$ after one day and was $18 \%$ after two days of the harvest time. This can be discussed as follow; $\alpha$-terpineol in our study recorded 19.01\% (June 2014), while it was of $2.7 \%$ (Malizia et al., 2011; Argentina; October), 2\% (Giatropoulos et al., 2013; Greece; June) and 0.8\% (Adams and Bartel, 2009; USA), according to its origin. In addition, the time of hydrodistillation have strong effect on the EOs constituents e.g., $\alpha$-terpineol recorded $(19.01 \%)$ in $5 \mathrm{hr}$, while it recorded $0.69 \%, 0.11 \%, 0.0 \%$ and $0.47 \%$ in $6,6-12,24$ and $24-48 \mathrm{hrs}$ respectively (Xinfeng, 2009).

Table 1: Chemical compositions of the essential oil of C. macrocarpa leaves.

\begin{tabular}{|c|c|c|c|c|c|c|}
\hline No & $\mathbf{R}_{\mathbf{t}}$ & Area \% & M.W. & M.F. & Main Fragments & Compound name \\
\hline 1 & 17.65 & 1.49 & 136 & $\mathrm{C}_{10} \mathrm{H}_{16}$ & $(41,53,65,69,77,79,91,93,121,136)$ & Camphene \\
\hline 2 & 19.75 & 1.24 & 134 & $\mathrm{C}_{10} \mathrm{H}_{14}$ & $(40,56,68,78,91,104,119,134)$ & $p$-Cymene \\
\hline 3 & 20.87 & 2.14 & 136 & $\mathrm{C}_{10} \mathrm{H}_{16}$ & $(41,51,77,91,93,105,121,136)$ & $\alpha$-Phellandrene \\
\hline 4 & 22.39 & 2.38 & 136 & $\mathrm{C}_{10} \mathrm{H}_{16}$ & $(41,516577,93,105,121,136)$ & $\alpha$-Terpinene \\
\hline 5 & 23.93 & 6.90 & 152 & $\mathrm{C}_{10} \mathrm{H}_{16} \mathrm{O}$ & $(41,43,55,6979,81,95,108,121,152)$ & 2-Pentyl-2-cyclopenten-1-one \\
\hline 6 & 25.24 & 19.01 & 154 & $\mathrm{C}_{10} \mathrm{H}_{18} \mathrm{O}$ & $(43,55,69,71,86,93,111,125,136,154)$ & $\alpha$-Terpineol \\
\hline 7 & 25.74 & 8.62 & 196 & $\mathrm{C}_{12} \mathrm{H}_{20} \mathrm{O}_{2}$ & $(43,53,55,59,71,79,93,111,121136,154,196)$ & $\alpha$-Terpinyl acetate \\
\hline 8 & 27.0 & 9.95 & ----- & ------ & $(41,43,55,67,69,81,95,109,123,138,156)$ & Unknown \\
\hline 9 & 34.61 & 3.38 & 204 & $\mathrm{C}_{15} \mathrm{H}_{24}$ & $(41,55,67,79,93,95,105,121,136,147,161,189$ & $(-)-\delta$-Elemene \\
\hline 10 & 35.24 & 8.75 & 198 & $\mathrm{C}_{13} \mathrm{H}_{26} \mathrm{O}$ & $(58,59,71,85,96,198)$ & 2-Tridecanone \\
\hline 11 & 35.53 & 8.92 & 222 & $\mathrm{C}_{15} \mathrm{H}_{26} \mathrm{O}$ & $(58,59,121,136,189,204)$ & Elemol \\
\hline 12 & 35.81 & 3.71 & 204 & $\mathrm{C}_{15} \mathrm{H}_{24}$ & $(58,94,105,135,161,204)$ & E-Santaline \\
\hline 13 & 37.22 & 3.54 & 218 & $\mathrm{C}_{15} \mathrm{H}_{22} \mathrm{O}$ & $(41,53,69,81,93,121,175,218)$ & Dendrolasin \\
\hline 14 & 40.85 & 5.83 & 284 & $\mathrm{C}_{15} \mathrm{H}_{26} \mathrm{O}$ & $(41,43,55,67,81,109,119,161,204,222)$ & $\beta$-Bisabolol \\
\hline 15 & 41.85 & 9.78 & 138 & $\mathrm{C}_{9} \mathrm{H}_{14} \mathrm{O}$ & $(41,67,69,81,93,107,136,138)$ & Camphenilone \\
\hline 16 & 47.80 & 0.74 & 272 & $\mathrm{C}_{20} \mathrm{H}_{32}$ & $(41,55,69,81,91,105,120,133,161,257,272)$ & Isophyllocladene \\
\hline 17 & 59.25 & 3.64 & ------ & ------- & $(57,71,83,113,121,149,167,279)$ & Unknown \\
\hline $\begin{array}{l}\text { Oxygenated } \\
\text { monoterpenes }\end{array}$ & & $25.91 \%$ & & & & \\
\hline $\begin{array}{l}\text { Oxygenated } \\
\text { sesquiterpenes }\end{array}$ & & $18.29 \%$ & & & & \\
\hline Monoterpenes & & $7.25 \%$ & & & & \\
\hline Sesquiterpenes & & $7.09 \%$ & & & & \\
\hline Diterpenes & & $0.74 \%$ & & & & \\
\hline Others & & $(27.15 \%)$ & & & & \\
\hline Unknown & & $13.59 \%$ & & & & \\
\hline Total identified & & $86.43 \%$ & & & & \\
\hline
\end{tabular}




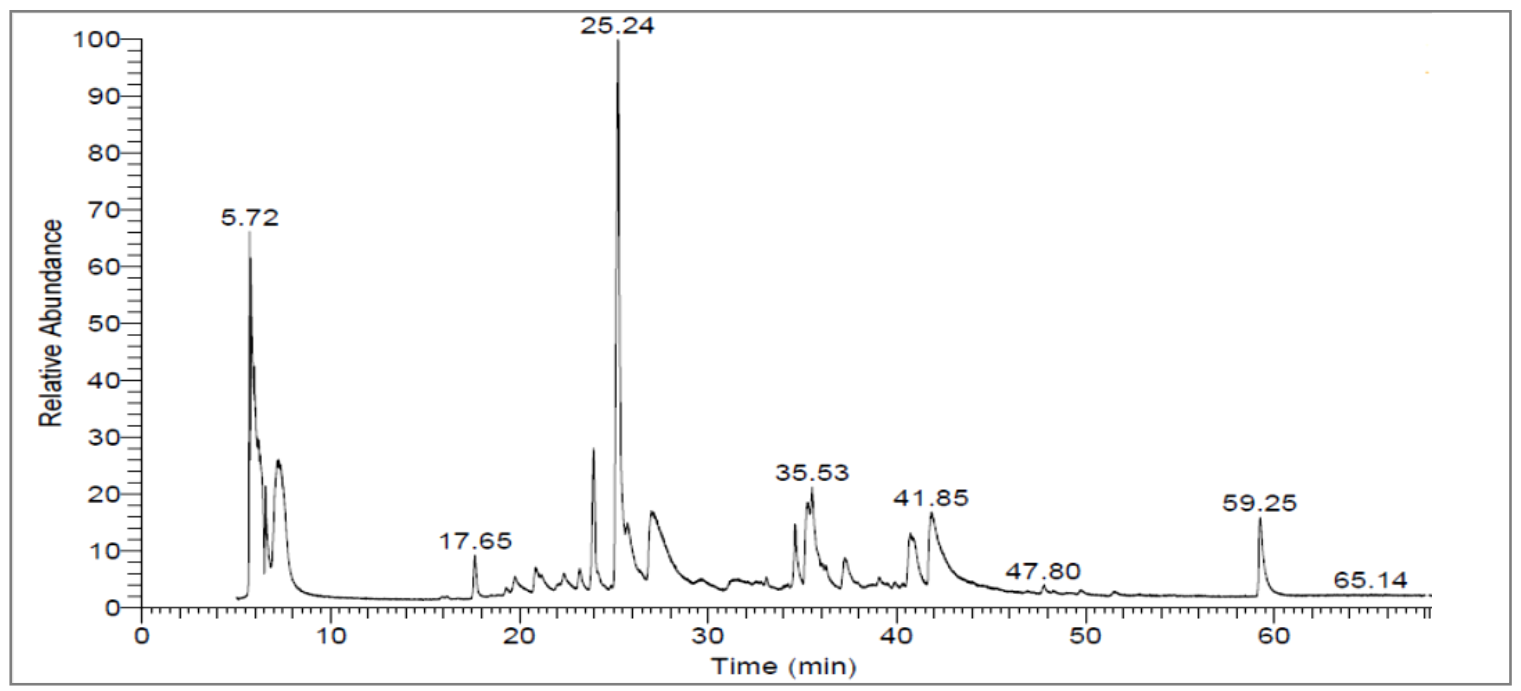

Fig. 1: GC-MS chromatogram of C. macrocarpa essential oil.

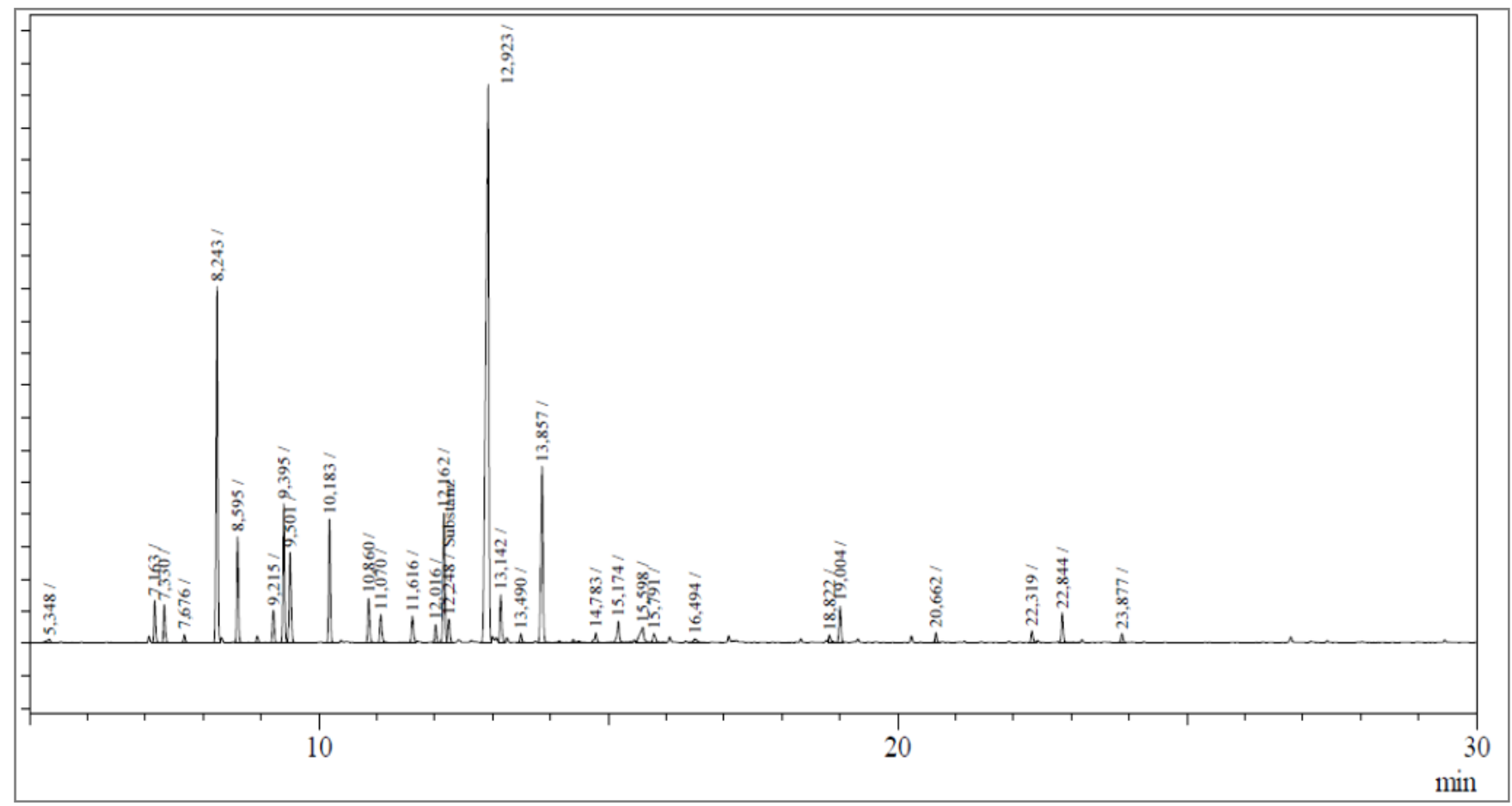

Fig. 2: GC/FID chromatogram of C. macrocarpa essential oil.

\section{Antimicrobial activity}

The antimicrobial activity of the essential oil was tested against $\mathrm{G}$ +ve and $\mathrm{G}$-ve bacteria and fungi. Generally, it has been found that the activity was decreased with increasing the dilution titer of the tested microbes. EO at dilution $(1: 5, \mathrm{v} / \mathrm{v})$ showed higher antifungal activity against $F$. oxysporum followed by $A$. niger and $F$. solani (17, 16 and $15 \mathrm{~mm})$, respectively, and it recorded activity against $C$. albicans with $(19 \mathrm{~mm})$. The potent antibacterial activity resulted at dilution of $1: 5, \mathrm{v} / \mathrm{v}$ against $P$. aeruginosa followed by $E$. coli with 21 and $15 \mathrm{~mm}$ for G-ve, and B. subtilis followed by S. aureus with 20 and $14 \mathrm{~mm}$ for
$\mathrm{G}+\mathrm{ve}$, respectively (Table 2). The MIC values proved that the oil inhibited the growth of the tested fungi and bacteria at dilution 1:12.5-50 (v/v), with Escherichia coli being the most sensitive (Table 3).

EOs exhibited promising antimicrobial activity against a wide range of bacteria, and are very useful in food industry and clinical practice (Nakatani, 1994). Usually, Gram +ve organisms are highly susceptible than Gram -ve (Burst, 2004) The activity of the EOs (i.e., antimicrobial) may be attributed to its major components (Lahlou, 2004), which may act synergistically (Peschel et al., 2006) to provide the activity. 
Table 2: Antimicrobial activities of the essential oil from C. macrocarpa leaves.

\begin{tabular}{|c|c|c|c|c|c|c|c|c|}
\hline Dilution v/v & $\begin{array}{c}\text { Fusarium } \\
\text { solani }\end{array}$ & $\begin{array}{c}\text { Fusarium } \\
\text { oxysporum }\end{array}$ & $\begin{array}{l}\text { Aspergillus } \\
\text { niger NRRL }\end{array}$ & $\begin{array}{l}\text { Candida } \\
\text { albicans }\end{array}$ & $\begin{array}{c}\text { Pseudomonas } \\
\text { aeruginosa }\end{array}$ & $\begin{array}{c}\text { Staphylococcus } \\
\text { aureus NRRL B- }\end{array}$ & $\begin{array}{c}\text { Escherichia coli } \\
\text { NRRL B-210 }\end{array}$ & $\begin{array}{l}\text { Bacillus subtilis } \\
\text { NRRL } 543\end{array}$ \\
\hline & Fungi & Fungi & Fungi & Yeast & $(\mathbf{G}$-ve) & $(G+v e)$ & $(G-v e)$ & $(G+v e)$ \\
\hline $1: 5$ & 15 & 17 & 16 & 19 & 21 & 14 & 15 & 20 \\
\hline $1: 25$ & 13 & 14 & 13 & 17 & 18 & 13 & 14 & 16 \\
\hline $1: 50$ & 12 & 12.5 & 12 & 15 & 15 & 12 & 12 & 12 \\
\hline 1:100 & 11 & 12 & 11 & 11 & 11 & 11 & 10.5 & 11.5 \\
\hline Streptomycin & -- & -- & -- & -- & 21 & 12 & 14 & 15 \\
\hline Nystatin & 17 & 18 & 15 & 15 & -- & 12 & -- & 11 \\
\hline
\end{tabular}

Inhibition zone diameter $(\mathrm{mm})$.

Table 3: MICs of the essential oil from C. macrocarpa leaves.

\begin{tabular}{|c|c|c|c|c|c|c|c|c|}
\hline Dilution v/v & $\begin{array}{c}\text { Fusarium } \\
\text { solani }\end{array}$ & $\begin{array}{c}\text { Fusarium } \\
\text { oxysporum }\end{array}$ & $\begin{array}{c}\text { Aspergillus } \\
\text { niger NRRL }\end{array}$ & $\begin{array}{l}\text { Candida } \\
\text { albicans }\end{array}$ & $\begin{array}{c}\text { Pseudomonas } \\
\text { aeruginosa }\end{array}$ & $\begin{array}{c}\text { Staphylococcus } \\
\text { aureus NRRL B- }\end{array}$ & $\begin{array}{c}\text { Escherichia coli } \\
\text { NRRL B-210 }\end{array}$ & $\begin{array}{c}\text { Bacillus subtilis } \\
\text { NRRL } 543\end{array}$ \\
\hline & Fungi & Fungi & Fungi & Yeast & (G -ve) & $(G+v e)$ & (G -ve) & $(G+v e)$ \\
\hline MIC (ml \% v/v) & -- & -- & -- & 12.5 & -- & 12.5 & 50 & 12.5 \\
\hline
\end{tabular}

Minimum Inhibition Concentration (MIC).

El-Ghorab et al., (2007) reported that the EO of Egyptian C. macrocarpa strongly inhibited the growth of $S$. aureus, $P$. aeruginosa, E. coli, A. niger and C. albicans, and concluded that, this may be attributed to the presence of neral, geraniol, eugenol dihydro, carvacrol acetate and phenol (2,6-dimethoxy). Moreover, Manimaran et al. (2007) reported the potent antimicrobial activity of the EO of the Indian C. macrocarpa and concluded that, such activity mainly due to the EO components i.e., caryophyllene, $\alpha$ terpineol etc. In addition, a comparative antimicrobial study was done on the EOs content of Cupressus glauca, C. funebris, C. lawsonia, C. macrocarpa and C. sempervirens. The results showed that $C$. macrocarpa possessed the potent antibacterial and antifungal activities at concentration of $100 \mathrm{mcg} / \mathrm{mL}$ while against C. albicans was $50 \mathrm{mcg} / \mathrm{mL}$ (Manivannan et al., 2005).

In the current study, $\alpha$-terpineol was reported to be the major component of the EO of $C$. macrocarpa, which was suspected to be responsible for the antimicrobial activity. Previous studies are in full agreement with our findings which correlated the antimicrobial activity to one or several major constituents. Yang et al. (2014) concluded that $\alpha$-terpineol and $p$-cymene are the reason for the antimicrobial activity of the EO of Glossogyne tenuifolia. Moreover, Krist et al. (2008) investigated the antimicrobial effect of five aroma compounds, among them $\alpha$-terpineol showed the highest activity. Kubo et al. (1991) proved that $\alpha$-terpineol has high antimicrobial activity against $S$. aureus, and $P$. aeruginosa.

In fact, the oxygenated monoterpenes (e.g. monoterpene alcohols) are promising antimicrobial agents due to the presence of the alcoholic part, which increase their water solubility (Hammer et al., 2003). Their mode of action may be attributed to protein denaturation or dehydration on the vegetative cells (Dorman and Deans, 2000). In addition, $\alpha$-terpineol as a member of the oxygenated monoterpenes can act as antimicrobial agent via the cell barrier destruction, and initiate seepage of proteins and lipids (Oyedemi et al., 2009). On the other hand, some studies have concluded that the antimicrobial activities of the whole essential oil were greater than the activities ascribed to certain individual constituents, and the synergistic effect should be taken in our minds due to a complex interaction between such individual constituents (Gill et al., 2002; Savelev et al., 2003).

\section{CONCLUSION}

The essential oil separated from the leaves of $C$. macrocarpa exhibited strong antimicrobial activity against Gram +ve \& -ve pathogenic strains, which may be attributed to the presence of $\alpha$-terpineol $(19.01 \%)$ as major component, or due to the synergistic effect between the overall constituents $\alpha$-terpineol (19.01\%), camphenilone $(9.78 \%)$, elemol (8.92\%), 2-tridecanone (8.75\%), $\alpha$-terpinyl acetate (8.62\%), 2-pentyl-2-cyclopenten-1-one (6.90\%) and $\beta$-bisabolol (5.83\%), therefore, it could be used in the treatment of microbial infections.

\section{Financial support and sponsorship: Nil.}

Conflict of Interests: There are no conflicts of interest.

\section{REFERENCES}

Adams RP. 1989. Identification of the essential oils by ion trap mass spectrometry. Academic press, INC, London, pp. 1-310.

Adams RP, Bartel JA. Geographic variation in the leaf essential oils of Hesperocyparis (Cupressus) abramsiana, $H$. goveniana and $H$. macrocarpa: systematic impications. Phytologia, 2009; 91:226-243.

Adams RP. Identification of essential oils by Gas Chromatography Quadrupole Mass Spectrometry. Carol Stream, Allured Publishing Co., Illinois, USA, 2001.

Adams RP. Identification of Essential Oils by Ion Trap Mass Spectroscopy. New York: Academic Press; 2012.

Al-Sayed E, Abdel-Daim MM. Protective role of Cupressuflavone from Cupressus macrocarpa against carbon tetrachloride-induced hepato- and nephrotoxicity in mice. Planta Med, 2014; 80(18):1665-1671. 
Bauer AW, Kirby WM, Sherris JC, Trucks M. Antibiotic susceptibility testing by a standardized single disk method. Am J Clin Pathol,1966; 45:493-496.

Boukhris M, Ghayth R, Thabet Y, Sami S, Mohamed B. Chemical composition and biological potential of essential oil from Tunisian Cupressus sempervirens L. J Arid Land Stud, 2012; 22(1):329332.

Briggs LH, Sutherland MD. The essential oil of Cupressus macrocarpa. J Org Chem, 1942; 07: 397-407.

Burst S. Essential oils: their antibacterial properties and potential application in foods. A review. Int J Food Microbial, 2004; 94223-94253.

Carson CF, Cookson BD, Riley TV. Susceptibility of methicillin resistant Staphylococcus aureus to the essential oils of Melaleuca alternifolia. J Antimicr. Chemother, 1995; 35: 421-424.

Cetin M, Sevik H, Isinkaralar K. Changes in the particulate matter and $\mathrm{CO}_{2}$ concentrations based on the time and weather conditions: the case of kastamonu. Oxid Commun, 2017 (in Press).

Cool LG. Sesquiterpenes from Cupressus macrocarpa foliage. Phytochem, 2005; 66:249-260.

Dorman HJD, Deans SG. Antimicrobial agents from plants: Antibacterial activity of plant volatile oils. J Appl Microbiol, 2000; 88:308-316.

Elgayyar M, Draughon FA, Golden DA, Mount JR. Antimicrobial activity of essential oils from plants against selected pathogenic and saprophytic microorganisms. J Food Protect, 2001; 64:1019-1024.

El-Ghorab AH, Khaled FE, Hamdy AS. Effect of drying on the chemical composition of the Egyptian Cupressus macrocarpa (Hartw.ex Gordon) essential oils and their biological characteristics. J Essent Oil Bear Plants, 2007; 10:399-411.

Emami SA, Mohammad HK, Rahimizadeh M, Bibi SF, Assilia J. Chemical constituents of Cupressus sempervirens L. cv. Cereiformis Rehd. essential oils. Iran J Pharm Sci, 2004; 1:39-42.

Ghareeb MA, Laila AR, Amal MS, Wafaa SA. Chemical composition, antioxidant and anticancer activities of the essential oil from Eucalyptus citriodora (Hook.) leaves. Der Pharm Chem, 2016; 8:192-200.

Giatropoulos A, Danae P, Fotini P, Dimitrios PP, George K, Nickolaos E, Olga T, Antonios M. Essential oil composition, adult repellency and larvicidal activity of eight Cupressaceae species from Greece against Aedes albopictus (Diptera: Culicidae). Parasitol Res, 2013; 112:1113-1123.

Gill AO, Delaquis P, Russo P, Holley RA. Evaluation of antilisterial action of cilantro oil vacuum packed ham. Int $\mathbf{J}$ Food Microbiol, 2002; 73:83-92.

Guney K, Cetin M, Sevik H, Kudret B G. Influence of germination percentage and morphological properties of some hormones practice on Lilium martagon L. seeds. Oxid Commun, 2016; 39(1-II):466474.

Hammer KA, Carson CF, Riley TV. Antifungal activity of the components of Melaleuca alternifolia (tea tree) oil. J Appl Microbiol, 2003; 95:853-860.

Ibrahim NA, El-Hawary SS, Mohammed MMD, Farid MA, Abdel-Wahed NAM, Ali MA, El-Abd EAW. Chemical composition, antiviral against avian influenza (H5N1) virus and antimicrobial activities of the essential oils of the leaves and fruits of Fortunella margarita, Lour. Swingle, growing in Egypt. J Appl Pharm Sci, 2015; 5:006-012.

Ibrahim NA, El-Seedi HR, Mohammed MMD. Constituents and biological activity of the chloroform extract and essential oil of Cupressus sempervirens. Chem Nat Compd, 2009; 45:309-311.

Krist S, Kei S, Sabine G, Martina H, Johannes S. Antimicrobial effect of vapours of terpineol, (R)-(-)-linalool, carvacrol, (S)-(-) perillaldehyde and 1,8-cineole on airborne microbes using a room diffuser. Flavour Fragr J, 2008; 23:353-356.

Kubo I, Himejima M, Muroi H. Antimicrobial activity of flavor components of cardamom Elattaria cardamomum (Zingiberaceae) seed. J Agric Food Chem, 1991; 39:1984-1986.
Lahlou M. Methods to study the phytochemistry and bioactivity of essential oils. Phytother Res, 2004; 18:435-448.

Linday EM (1962). Practical introduction to microbiology. (E. and FN spon Ltd), UK.

Malizia RA, Daniel AC, José SM, Silvia G, Pedro EG, Ricardo JG. Volatile constituents of leaf oils from the Cupressaceae Family: Part I. Cupressus macrocarpa Hartw., C. arizonica Greene and C. torulosa Don species growing in Argentina. J Essent Oil Res, 2011; 12:59-63.

Manimaran S, Themozhil S, Nanjan MJ, Suresh B. Chemical composition and antimicrobial activity of cone volatile oil of Cupressus macrocarpa Hartwig from Nilgiris, India. Nat Prod Sci, 2007; 13:279-282.

Manivannan R, Kumar MS, Jawahar N, Ganesh ES, Jubie S. A comparative antimicrobial study on the essential oil of the leaves of various species of Cupressus. Anc Sci Life 2005; XXIV131-133.

Nakatani N. 1994. Antioxidative and antimicrobial constituents of herbs and spices. In: Charalambous G, editor. Spices, Herba and Edible Fungi. Elsevier: New York, 251-271.

Oyedemi SO, Okoh A, Mabinya LV, Pirochenva G, Afolayan AJ. The proposed mechanism of bactericidal action of eugenol, $\alpha$-terpineol and $\gamma$-terpinene against Listeria monocytogenes, Streptococcus pyogenes, Proteus vulgaris and Escherichia coli. Afr J Biotechnol, 2009; 8:12801286.

Peschel W, Sánchez-Rabaneda F, Diekmann W, Plescher A, Gartzy I, Jiménez D. An industrial approach in the search of natural antioxidants from vegetable and fruit wastes. Food Chem, 2006; 97:137150.

Savelev S, Okello E, Perry NSL, Wilkins RM, Perry EK. Synergistic and antagonistic interactions of anticholinesterase terpenoides in Salvia lavandulaefolia essential oil. Pharmacol Biochem Behavior, 2003; 75:661-668.

Sevik H, Cetin M, Guney K, Belkayali N. Influences of certain indoor plants on indoor $\mathrm{CO}_{2}$ amount. Polish J Environ Stud, 2017 (In Press).

Sevik H, Cetin M, Ozkan K. Effect of light on young structure of Turkish fir (Abies nordmanniana subsp. Bornmulleriana). Oxid Commun, 2016; 39(1-II):485-492.

Sevik H, Cetin M. Effects of Some hormone applications on germination and morphological characters of endangered plant species Lilium Artvinense L. onion scales. Bulgarian Chem Commun, 2016; 48(2):256-260.

Thukral SK., Sumitra S, Surendra KS. Pharmacognostical standardization of leaves of Cupressus macrocarpa Hartweg. ex Gordon. J Appl Pharm Sci, 2014; 4:071-074.

Xinfeng L. Analysis and comparison of essential oil components extracted from the heartwoods of Leyland Cypress, Alaska Yellow Cedar, and Monterey Cypress. Dissertation, Oregon State University, 2009.

Yang T, Louis KC, Tai-Ti L. Antimicrobial activity of the essential oil of Glossogyne tenuifolia against selected pathogens. J Sci Food Agric, 2014; 94:2965-2971.

Yigit N, Sevik H, Cetin M, Gul L. Clonal variation in chemical wood characteristics in hanönü (kastamonu) günlüburun black pine (Pinus nigra Arnold. subsp. pallasiana (Lamb.) Holmboe) Seed Orchard. J Sus Forestry, 2016; 35 (7):515-526.

Zheljazkov VD, Cantrell CL, Astatkie T, Jeliazkove E. Distillation Time effect on Lavender essential oil yield and composition. J Oleo Sci, 2013; 62:195-199.

\section{How to cite this article:}

Saad AM, Mohammed MMD, Ghareeb MA, Ahmed WS, Farid MA. Chemical Composition and Antimicrobial Activity of the Essential Oil of the Leaves of Cupressus macrocarpa Hartweg. ex Gordon. J App Pharm Sci, 2017; 7 (09): 207-212. 